\title{
ACTION OF OESTROGEN ON THE BLASTOCYST AND UTERUS IN DELAYED IMPLANTATION- AN AUTORADIOGRAPHIC STUDY
}

\author{
M. R. N. PRASAD, G. M. S. DASS AND SURESH MOHLA \\ Department of Zoology, University of Delhi, Delhi-7, India \\ (Received 6th fune 1967, revised 22nd August 1967)
}

\begin{abstract}
Summary. The metabolic changes in the pre-implantation blastocyst have been studied by instillation of ${ }^{3} \mathrm{H}$-cytidine, ${ }^{3} \mathrm{H}$-phenyl alanine and ${ }^{3} \mathrm{H}$-thymidine into the uterine lumen in experimentally induced delayed implantation and at specific time intervals after the administration of oestrogen.

Minimal RNA synthesis occurs in the blastocyst and uterus during delayed implantation. Minimal protein synthesis is seen only in the uterine epithelium during this period. Oestrogen enhances the synthesis of RNA, DNA and protein in the blastocyst while only RNA and protein synthesis are activated in the uterus. The significance of these oestrogeninduced changes in the blastocyst and uterus is discussed in relation to implantation.
\end{abstract}

\section{INTRODUCTION}

Delayed implantation, occurring naturally during lactation or induced experimentally, results in the arrest of development of blastocysts. Such delayed blastocysts implant following the removal of litter during lactational delay or after oestrogen administration (Eckstein, 1959).

Induced delayed implantation offers an ideal experimental design for the study of the relation between the time of administration of oestrogen and the onset of changes in the blastocyst and uterus leading to implantation. Weitlauf \& Greenwald (1965) using the lactational delay of implantation in mice showed an enhanced incorporation of ${ }^{35} \mathrm{~S}$-methionine, indicative of protein synthesis, $24 \mathrm{hr}$ after the removal of the young in a manner comparable to the condition on the 5th day of normal implantation. However, some of the other workers have encountered difficulties in in-vivo labelling pattern in the pre-implantation stages of blastocysts which may be due to (a) dilution of the precursors by the pre-existing pools in the various tissues of the animal, (b) competitive utilization of the precursors by tissues other than the target sites, i.e. uterus and blastocyst, and (c) the failure to synchronize the availability of the precursors with the initiation of activity in the blastocysts. In the present experiment some of these difficulties were overcome by direct instillation of the precursors into the uterine lumen, and the changes occurring in the blastocyst and uterus following oestrogen administration were studied. 


\section{MATERIAL AND METHODS}

Colony bred, adult, virgin, female albino rats of the Holtzman strain, ranging in weight from 220 to $280 \mathrm{~g}$, were used. They were housed in air-conditioned rooms (temperature was maintained at $78 \pm 2^{\circ} \mathrm{F}$ ) and fed a balanced diet supplemented by milk and bread. Tap water was freely available for drinking.

Females in pro-oestrus were caged with males of proved fertility and left overnight. Mating was confirmed by the presence of spermatozoa in the vaginal smear on the following morning which was considered as Day 1 of pregnancy.

Delayed implantation was induced following the method of Cochrane \& Meyer (1957). Mated females were bilaterally ovariectomized on Day 3 of pregnancy. On the day of ovariectomy and thereafter, each rat was administered subcutaneously $4 \mathrm{mg}$ of progesterone/day in $0.25 \mathrm{ml}$ of olive oil until the termination of the experiment. Surgical procedures were done under light ether anaesthesia using semi-sterile conditions.

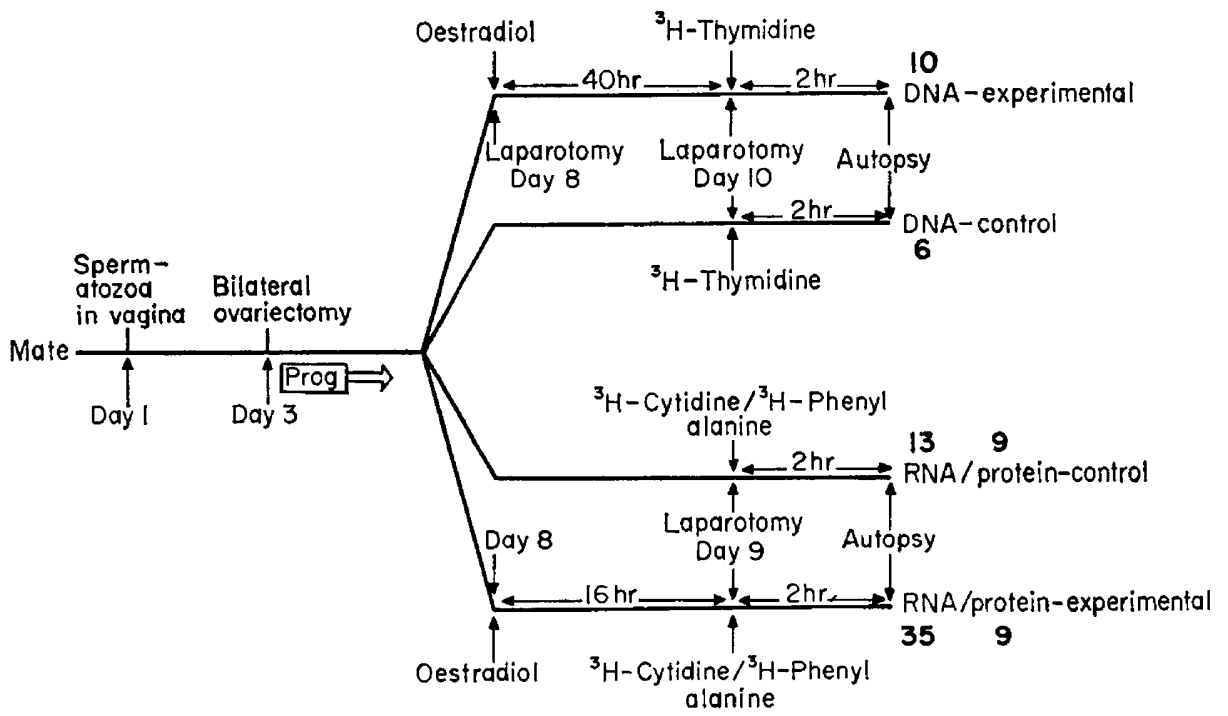

Text-fig. 1. Schematic representation of the experimental design. Prog: $4 \mathrm{mg} / \mathrm{day}$ of progesterone injected from the day of ovariectomy until the termination of the experiment. Bold figures indicate the number of blastocysts used for autoradiographic study.

\section{Administration of the precursor}

The uteri were exteriorized by midventral incision. The uterine horns were ligated at the cervical ends, taking care to exclude the blood vessels. The precursors were instilled into the uterine lumen by means of a 26-gauge needle from the tubal end which was ligated after the withdrawal of the needle to avoid leakage of the precursor into the peritoneal cavity. The duration of exposure to the precursor was $2 \mathrm{hr}$ in all the groups.

Rats in which implantation was experimentally delayed by ovariectomy and progesterone treatment were used on Days 8 to 10 of pregnancy. The experimental design is shown in Text-fig. 1. The rats were divided into three 
groups each of which was further subdivided into a control and experimental set. The control in all cases refers to the condition during delayed implantation and the blastocysts are referred to as 'delayed blastocysts'. 'Experimental' refers to the condition following the administration of oestradiol-17 $\beta$ and the blastocysts are referred to as 'active blastocysts'.

\section{$R \mathcal{N} A$ and protein synthesis}

Control. The precursors, ${ }^{3} \mathrm{H}$-cytidine (specific activity $6.0 \mathrm{c} / \mathrm{m}$-mole, Lot No. 6601 , Schwarz Bio-Research; $10 \mu \mathrm{c} /$ uterine horn in $0.1 \mathrm{ml}$ sterile physiological saline) for RNA synthesis or ${ }^{3} \mathrm{H}$-phenyl alanine (specific activity 2.5 $\mathrm{c} / \mathrm{m}$-mole, Lot No. 6603, Schwarz Bio-Research; $10 \mu \mathrm{c} / \mathrm{uterine}$ horn in 0.05 ml sterile physiological saline) for protein synthesis, were instilled into the uterine horns at laparotomy on Day 9. The animals were autopsied $2 \mathrm{hr}$ later. The uterine horns were flushed for blastocysts.

Experimental. Rats were injected subcutaneously with $1 \mu \mathrm{g}$ of oestradiol-17 $\beta$ in $0.08 \mathrm{ml}$ of olive oil on Day $8 ; 16 \mathrm{hr}$ after the administration of oestrogen the animals were laparotomized. If no implantation sites were present, the precursors were instilled into the uterine horns. They were autopsied $2 \mathrm{hr}$ later and blastocysts collected from uterine flushings.

\section{$D \mathcal{N A}$ synthesis}

Control. The precursor, ${ }^{3} \mathrm{H}$-thymidine (specific activity $14.0 \mathrm{c} / \mathrm{m}$-mole, Lot No. 13605, Schwarz Bio-Research; $5 \mu \mathrm{c} /$ uterine horn in $0.05 \mathrm{ml}$ sterile physiological saline) was instilled into the uterine lumen on Day 10 . The animals were autopsied $2 \mathrm{hr}$ later and the uterine horns were flushed for blastocysts.

Experimental. Rats were laparotomized on Day 8 to check for implantation sites. If no sites were present, each rat was given subcutaneously $1 \mu \mathrm{g}$ of oestradiol- $17 \beta$ in $0.08 \mathrm{ml}$ of olive oil; $40 \mathrm{hr}$ following the oestrogen treatment the precursor was instilled into the uterine horns. They were autopsied $2 \mathrm{hr}$ later and the uterine horns were flushed for blastocysts.

\section{Collection of blastocysts and fixation}

The animals were killed at the appropriate time and the uteri dissected free of fat and connective tissue. The uterine horns were flushed from the tubal ends with the respective cold precursors in sterile physiological saline or saline only. The concentration of cold precursors in the flushing media was 100 times more than that used for instillation. The blastocysts were washed quickly two or three times with the flushing medium, transferred to subbed slides, air dried and later fixed in Carnoy's for 5 min.

Respective uteri from which blastocysts were flushed were further washed two or three times with the flushing media and fixed in Carnoy's for $30 \mathrm{~min}$, washed in water and frozen in a cryostat at $-22^{\circ}$ to $-28^{\circ} \mathrm{C}$. Cryostat sections, $4 \mu$ thick, were transferred to clean slides and air dried.

The sections of uteri as well as the blastocysts were treated with $2 \%$ perchloric acid at $4^{\circ} \mathrm{C}$ for $20 \mathrm{~min}$ to remove free nucleotides. Ribonuclease extraction $\left(1 \mathrm{mg} / \mathrm{ml}\right.$ at $37^{\circ} \mathrm{C}$ for $2 \mathrm{hr}$ ) of the control and experimental uterine sections 
as well as of the control blastocyst was done to remove RNA and confirm the specificity of incorporation of the precursor.

The slides were coated with diluted $(1: 1)$ Kodak nuclear track emulsion NTB3 and the autoradiographs were developed after 15 days of exposure. The autoradiographs were developed in Kodak D-19 for $7 \mathrm{~min}$ at $18^{\circ} \mathrm{C}$ and acid fixed. The material was stained through the emulsion with buffered Azure B or buffered methyl green-pyronine.

\section{RESULTS}

\section{Control}

RNA SYNTHESIS

Blastocyst. Two levels of incorporation of the precursor were observed in the blastocyst. The density of the grains was comparatively more in the cells of the inner cell mass than in those of the trophoblast (Pl. 1, Fig. 1). This indicates that while all the cells of the blastocyst synthesize RNA relatively more is synthesized in the cells of the inner cell mass.

Uterus. Very few grains were seen in the cells of the uterine epithelium indicating a minimal RNA synthesis (Pl. 2, Fig. 5).

\section{Experimental}

Blastocyst. The blastocyst showed a general increase in the incorporation of the precursor. It was particularly heavy in the inner cell mass. The grains were localized in the nucleus (Pl. 1, Figs. 2 to 4). The blastocysts flushed $18 \mathrm{hr}$ after oestrogen treatment did not show any change either in size or morphology compared to those during delayed implantation.

Uterus. The uterus showed a marked increase in the density of the grains in the epithelium indicating a considerable enhancement of RNA synthesis between 16 and $18 \mathrm{hr}$ after the administration of oestrogen, i.e. $2 \mathrm{hr}$ of exposure to the precursor (Pl. 2, Fig. 6).

Specificity of incorporation of the precursor into the RNA seen in the uterus and blastocyst was confirmed by treatment with ribonuclease (Pl. 2, Figs. 7 and 8). No grains were seen in such extracted tissues.

\section{Control}

\section{PROTEIN SYNTHESIS}

Blastocyst. There was no evidence of protein synthesis as shown by the absence of incorporation of the precursor in any region of the blastocyst (Pl. 3, Fig. 11).

Uterus. Minimal protein synthesis was seen in the uterine epithelium (P1. 3, Fig. 13).

\section{Experimental}

Blastocyst. The blastocyst showed a marked uptake of the precursor in the inner cell mass compared to a minimal incorporation in the other regions (Pl. 3, Fig. 12). This probably indicates differential rates of protein synthesis in the different regions of the blastocyst following oestrogen treatment.

Uterus. Oestrogen treatment caused a marked increase in the density of the 
grains in the uterine epithelium and also in the stromal cells of the endometrium (Pl. 3, Fig. 14).

Control

\section{DNA SYNTHESIS}

Blastocyst. There was no evidence of DNA synthesis as shown by the absence of incorporation of the precursor in any region of the blastocyst (Pl. 4, Fig. 15). Occasional mitoses were also noticed in this region (Pl. 4, Fig. 17).

Uterus. None of the regions of the uterus including the uterine epithelium showed any evidence of DNA synthesis (P1. 2, Fig. 9).

\section{Experimental}

Blastocyst. Heavy incorporation of the precursor was seen in some of the cells of the inner cell mass and trophoblast (Pl. 4, Figs. 16 and 18). The blastocysts were elongated and in the form of a ball of cells and were sticky.

Uterus. There was no incorporation of the precursor either in the uterine epithelium or in any other region of the endometrium $42 \mathrm{hr}$ after oestrogen treatment (Pl. 2, Fig. 10).

\section{DISCUSSION}

Implantation of the blastocysts occurs in the rat on Day 5 p.c. when the uterus has undergone pre-implantation changes as a result of synergistic action of progesterone and oestrogen. However, during delayed implantation, the blastocysts are prevented from implantation and are maintained for a number of days in a state of suspended animation without loss of viability. Such 'delayed' blastocysts implant following the removal of the litter during lactational delay (Krehbiel, 1941), after administration of oestrone along with progesterone (Cochrane \& Meyer, 1957) in experimentally induced delayed implantation, and after oestrone or LH treatment in rats bearing pituitary autografts (Cochrane, Prasad \& Meyer, 1962; MacDonald, Armstrong \& Greep, 1967). Oestrogen-induced implantation of the delayed blastocyst offers a method for a study of the time sequence of action of oestrogen on the blastocysts and uterus. Using this technique it has been possible to study the pattern of RNA, DNA and protein synthesis in the delayed and active blastocysts and uterus. This study also provides an insight into the possible action of oestrogen on the preimplantation blastocyst either directly or mediated through the uterus. In our experiments the time interval after oestrogen administration, namely $18 \mathrm{hr}$ for the demonstration of RNA and protein synthesis and $42 \mathrm{hr}$ for the demonstration of DNA synthesis, was chosen since these oestrogen-induced synthetic processes are clearly demonstrable in the uterus during this period (Mueller, 1960, 1964; Schmidt, Walther \& Voigt, 1966).

Our results show that minimal RNA synthesis occurs in the delayed blastocysts. There is no particular localization of the grains in the cells of the blastocysts at this stage. Protein synthesis, as indicated by the incorporation of phenyl alanine, appears to be minimal in the delayed uterus, whereas the delayed blastocyst does not show evidence of protein synthesis. Administration of 
oestrogen markedly changes the picture with reference to both these constituents. The level of RNA synthesis is enhanced considerably $18 \mathrm{hr}$ after the administration of oestrogen. Two points are of interest here. The increased RNA synthesis is particularly marked in the cells of the inner cell mass compared to those of the other regions of the blastocyst; secondly, there is a localization of the grains in the nucleus of the cells of the inner cell mass. This indicates a possibility that the new RNA synthesized following oestrogen treatment is DNA-dependent. However, this cannot be stated unequivocally on the basis of the present study; also it is not clear how soon after oestrogen administration the synthesis of RNA is initiated in the delayed blastocyst.

Protein synthesis in the blastocyst follows a similar pattern. There is enhanced protein synthesis more markedly in the inner cell mass than in the cells of the trophoblast of the active blastocyst. These results confirm the observations of Weitlauf \& Greenwald (1965).

DNA synthesis in the blastocyst and uterus follows a different pattern. Very little DNA synthesis occurs in the delayed blastocyst. However, significant DNA synthesis is seen in some of the cells of the inner cell mass $42 \mathrm{hr}$ after oestrogen administration. This indicates that oestrogen induces mitogenic activity in the blastocyst. On the other hand, the uterus is as yet unresponsive and does not show evidence of DNA synthesis either during delayed implantation or $42 \mathrm{hr}$ after oestrogen treatment. Thus, oestrogen seems to have a differential time sequence of action on the cells of the blastocyst and uterus.

The question in regard to the problem of activation of the delayed blastocyst is whether activation is caused by a direct action of oestrogen or whether it is mediated through the stimulatory action of oestrogen on the uterus. Our results, particularly that of differential action of oestrogen on DNA synthesis in the blastocyst and uterus, provide some evidence of a possible direct stimulation of the delayed blastocyst by oestrogen. Further work to elucidate the problem is in progress.

The delayed blastocysts remain in a dormant state without any appreciable increase in the number of cells; mitotic activity in the inner cell mass is completely inhibited (Baevsky, 1963). Our results show that occasional mitoses are seen in the inner cell mass of the delayed blastocyst.

The technique of intra-uterine instillation described in the present study offers a method of in-vivo incubation of the blastocysts with appropriate precursors and enables a study of the time sequence of action of oestrogen on the activation of synthetic processes in the pre-implantation blastocyst and uterus.

\section{ACKNOWLEDGMENTS}

This investigation was supported by a grant from the Ford Foundation. The authors thank Dr B. R. Seshachar for his interest in this study. Thanks are due to Mr E. A. Daniels for help in photomicrography and to Mr K. L. Bhalla in the preparation of the illustration.

\section{REFERENCES}

BAEVSKy, U. B. (1963) The effect of embryonic diapause on the nuclei and mitotic activity on mink and rat blastocysts. In: Delayed Implantation. Ed. A. C. Enders. University of Chicago Press. 
Cochrane, R. L. \& Meyer, R. K. (1957) Delayed nidation in the rat induced by progesterone. Proc. Soc. exp. Biol. Med. 96, 155.

Cochrane, R. L., Prasad, M. R. N. \& Meyer, R. K. (1962) Delayed nidation in the rat induced by autografts of the hypophysis with a case report of asynchronous implantation. Endocrinology, 70, 228.

Eckstein, P. (1959) Implantation of ova. Mem. Soc. Endocr. No. 6.

KREHBIEL, R. H. (1941) The effect of lactation on the implantation of the ova of a concurrent pregnancy in the rat. Anat. Rec. 81, 381.

MacDonald, G. J., Armstrong, D. T. \& Greep, R. O. (1967) Initiation of blastocyst implantation by luteinizing hormone. Endocrinology, 80, 172 .

Mueller, G. G. (1960) Biochemical parameters of estrogen action. In: Biological Activities of Steroids in Relation to Cancer, p. 129. Academic Press, New York.

Mueller, G. C. (1964) The role of RNA and protein synthesis in estrogen action. Proc. 2nd int. Congr. Endocr. International Congress Series No. 83, Excerpta Medica Foundation.

Schmidr, V. H., Walther, H. \& Voigt, K. D. (1966) Der Einfluss von Ostradiol auf den Gehalt des Rattenuterus an Nucleinsauren, Protein and Enzymaktivitaten. Enzym. Biol. Clin. (Basel) 7, 239.

Weitlauf, H. M. \& Greenwald, G. S. (1965) A comparison of ${ }^{35} \mathrm{~S}$ methionine incorporation by the blastocysts of normal and delayed implanting mice. F. Reprod. Fert. 10, 203. 


\section{PLATE 1}

Fic. 1. Delayed blastocyst after $2 \mathrm{hr}$ of exposure to ${ }^{3} \mathrm{H}$-cytidine. Azure B. $\times 600$.

Fig. 2. Active blastocyst exposed for $2 \mathrm{hr}$ to ${ }^{3} \mathrm{H}$-cytidine following a single injection of oestradiol $16 \mathrm{hr}$ earlier. The dark mass on the left hand top corner of the blastocyst is a dust particle. Azure B. $\times 600$.

Fig. 3. Part of the trophoblast of the active blastocyst shown in Fig. 2. Note the sparse uptake of the label in the trophoblastic cells. Compare with Fig. 4. Azure B. $\times 1400$.

FIG. 4. Part of the inner cell mass of blastocyst shown in Fig. 2. Note the marked increase in the label in the cells compared to those in Fig. 3. The grains are localized in the nucleus. Azure B. $\times 1400$.

\section{PLATE 2}

FIG. 5. Uterus of a delayed rat $2 \mathrm{hr}$ after intraluminal instillation of ${ }^{3} \mathrm{H}$-cytidine. The precursor is localized in the uterine epithelium. Azure B. $\times 1400$.

Fic. 6. Uterus of an experimental rat $2 \mathrm{hr}$ after intraluminal instillation of ${ }^{3} \mathrm{H}$-cytidine following a single injection of oestradiol $16 \mathrm{hr}$ earlier. Note the enhanced incorporation of precursor in the uterine epithelium. Compare with Fig. 5. Azure B. $\times 1400$.

Figs. 7 and 8. The uteri shown in Figs. 5 and 6 following extraction with ribonuclease. Note the absence of the grains in the epithelium. Azure B. $\times 1400$.

FIG. 9. Uterus of a delayed rat $2 \mathrm{hr}$ after intraluminal instillation of ${ }^{3} \mathrm{H}$-thymidine. Note the absence of precursor in the uterus. Methyl green-pyronine. $\times 900$.

Fig. 10. Uterus of an experimental rat $2 \mathrm{hr}$ after intraluminal instillation of ${ }^{3} \mathrm{H}$-thymidine following a single injection of oestradiol $40 \mathrm{hr}$ earlier. Note the sparse isolated grains in the uterine epithelium and endometrium. Methyl green-pyronine. $\times 900$.

\section{PLATE 3}

Fig. 11. Delayed blastocyst after $2 \mathrm{hr}$ of exposure to ${ }^{3} \mathrm{H}$-phenyl alanine. Methyl greenpyronine. $\times 600$.

Fig. 12. Active blastocyst exposed for $2 \mathrm{hr}$ to ${ }^{3} \mathrm{H}$-phenyl alanine following a single injection of oestradiol $16 \mathrm{hr}$ earlier. Note the marked uptake of the precursor in the inner cell mass compared to the other regions of the blastocyst. Compare with Fig. 11. Methyl greenpyronine. $\times 600$.

Fig. 13. Part of the uterine epithelium of a delayed rat $2 \mathrm{hr}$ after intraluminal instillation of ${ }^{3} \mathrm{H}$-phenyl alanine. Note the uptake of the precursor in the uterine epithelium. Methyl green-pyronine. $\times 1100$.

Fig. 14. Part of the uterine epithelium of an experimental rat $2 \mathrm{hr}$ after exposure to ${ }^{3} \mathrm{H}$ phenyl alanine following a single injection of oestradiol $16 \mathrm{hr}$ earlier. Note the marked increase in the localization of the precursor in the uterine epithelium as well as in the endometrium. Methyl green-pyronine. $\times 1100$.

\section{PLATE 4}

Fig. 15. Delayed blastocyst after $2 \mathrm{hr}$ of exposure to ${ }^{3} \mathrm{H}$-thymidine. Note the absence of uptake of the precursor in any region of the blastocyst. Methyl green-pyronine. $\times 600$.

Fig. 16. Active blastocyst exposed for $2 \mathrm{hr}$ to ${ }^{3} \mathrm{H}$-thymidine following a single injection of oestradiol $40 \mathrm{hr}$ earlier. Note the marked increase in the uptake of the precursor in some cells of the inner cell mass. Stained in Feulgen before coating with emulsion. $\times 600$.

FIG. 17. One of the cells of the inner cell mass of the delayed blastocyst shown in Fig. 15 undergoing division. Methyl green-pyronine. $\times 1600$.

Fig. 18. Part of inner cell mass of blastocyst shown in Fig. 16. Note the marked uptake of the precursor. Compare with Figs. 15 and 17. Stained in Feulgen before coating with emulsion. $\times 1600$. 
PLA'TE I

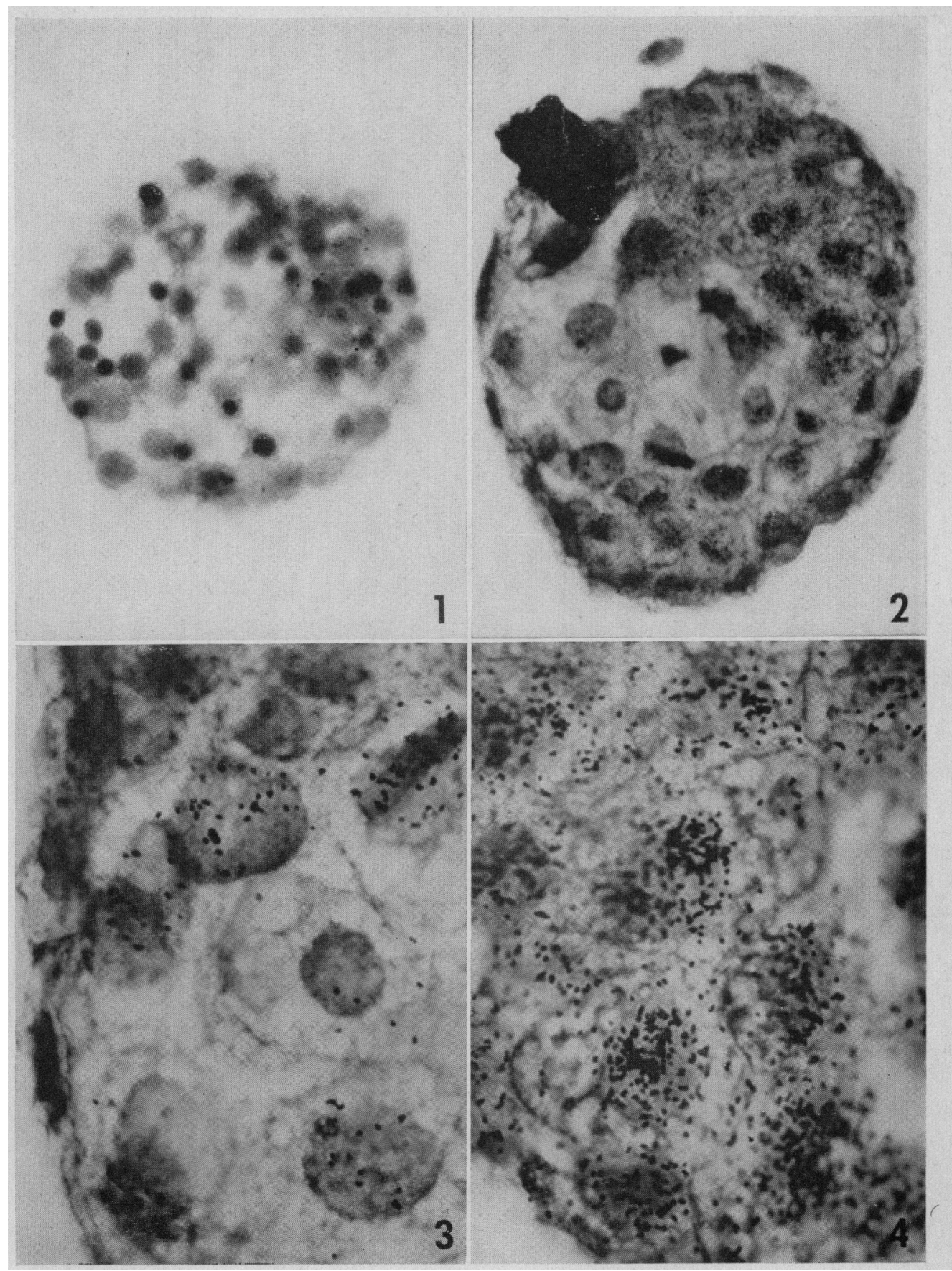




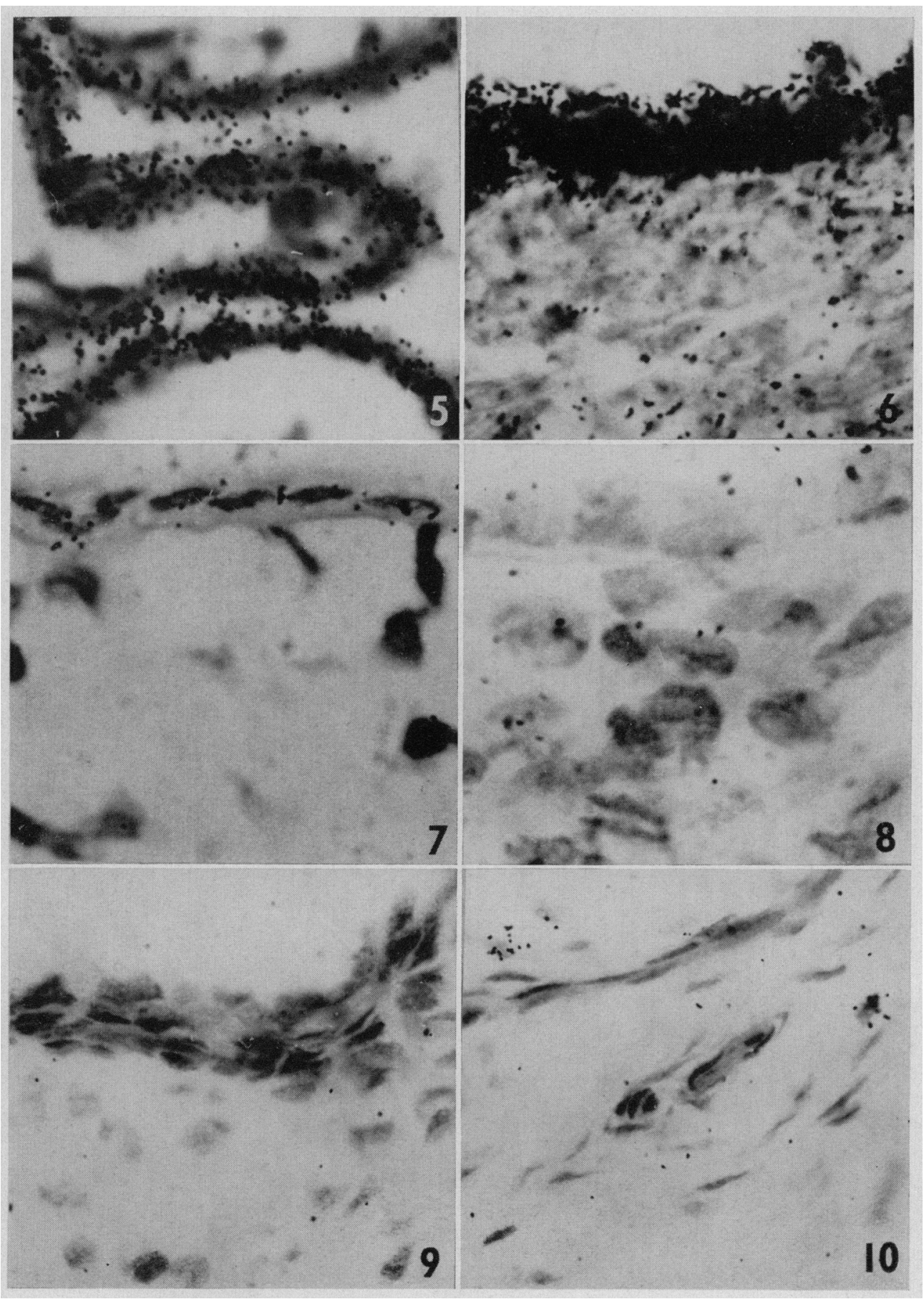




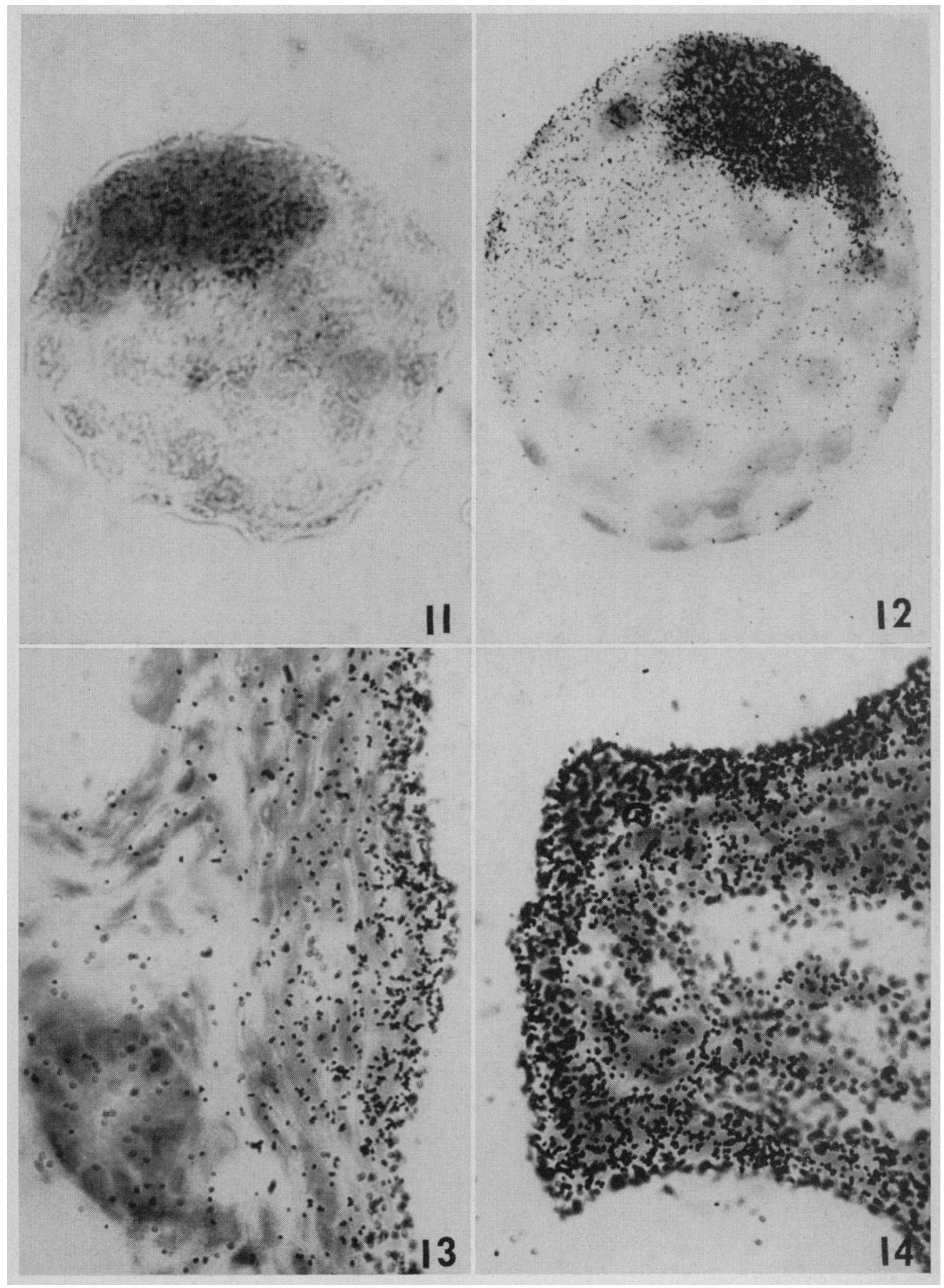


PLATE 4

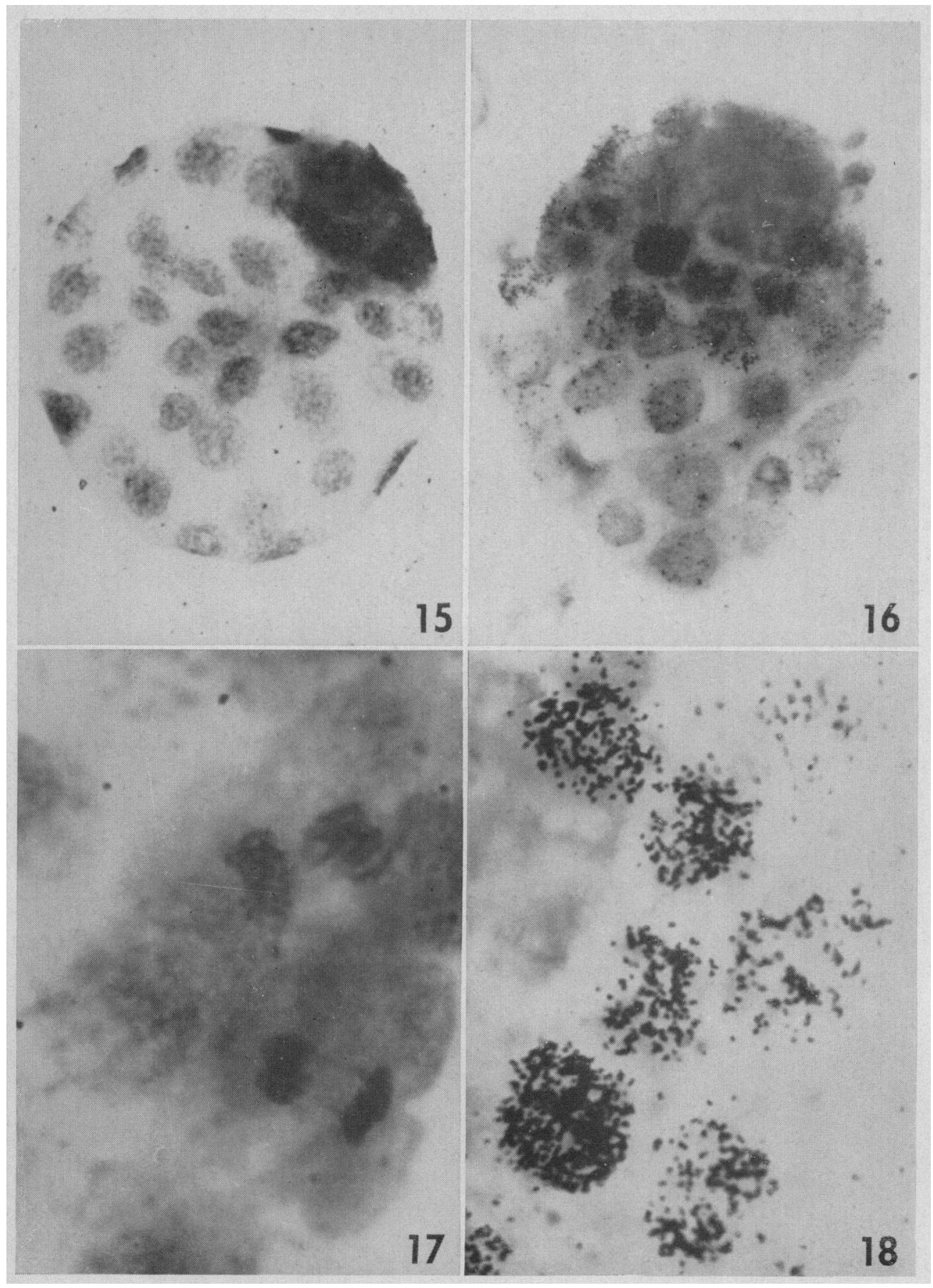

